\title{
Bibliometric and altmetric analysis of publications examining education methods in realm of anatomy
}

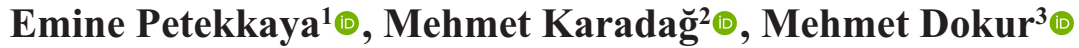 \\ ${ }^{1}$ Department of Anatomy, Kastamonu University School of Medicine, Kastamonu, Turkey \\ ${ }^{2}$ Department of Biostatistics, Mustafa Kemal University School of Medicine, Hatay, Turkey \\ ${ }^{3}$ Department of Emergency Medicine, Biruni University School of Medicine, Istanbul, Turkey
}

\begin{abstract}
Objectives: This study aimed to investigate the significance of publications examining the effectiveness of education methods in the field of anatomy with the method of bibliometric and altmetric analysis, as well as online attention levels.

Methods: To search all publications, "Anatomy education" was entered as a search term on the Web of Science database. The topics, journal impact factors, publication years and research centers of the first 100 articles with the highest numbers of citations were examined, and their analysis was conducted with the "Altmetric it on website: http: almetric.com".
\end{abstract}

Results: Four thousand, three hundred fifty-six articles published in the period of 1975-2019 containing the key phrase "Anatomy education" were found on Web of Science. The study with the highest number of citations was the study published by McLachlan et al. titled "Teaching anatomy without cadavers, 2004". It was observed that the study titled "The production of anatomical teaching resources using three-dimensional (3D) printing technology, 2014" was the article with the highest rate of sharing on Twitter with the highest altmetric attention score (AAS) value. The AAS rates varied between 130 and 0.

Conclusions: Bibliometric and altmetric analysis provides significant but different points of view regarding the effects of an article in the world of science. The altmetrics score may provide contributions in determining the direction of studies regarding the high-level interests and perceptions of the public on dynamic science and the field of medicine.

Keywords: Bibliometric, altmetrics, analysis, anatomy, educational methods

$\mathrm{t}$ is important to assess the effectiveness of medical education in today's conditions with evidencebased analyses, because these assessments have the potential of directing practices of developing curricula. While anatomy education is the building block of medicine, it is seen by students as a difficult to learn subject at the beginning of medical education [1]. The rapid development of technology has allowed devel- opment of various methods that present the practical ways of learning anatomy today. The practices of anatomy education have been enriched by cadaver dissection coming from traditional medical education, followed by plastic modellings of body parts and highly diverse online electronic sources that provide information gathering methods today, interactive three-dimensional (3D) visualization technologies and

How to cite this article: Petekkaya E, Karadağ M, Dokur M. Bibliometric and altmetric analysis of publications examining education methods in realm of anatomy. Eur Res J 2021;7(4):391-408. DOI: 10.18621/eurj.776229

Address for correspondence: Emine Petekkaya, MD., Assistant Professor, Kastamonu University School of Medicine, Department of Anatomy, Orgeneral Atilla Ates Pasa Ave, Kuzeykent Neighb, 37150, Kastamonu, Turkey. E-mail: eminepetekkaya@gmail.com, Tel: +90 3662803501 
"multimodal" approaches such as radiological imaging [2]. Especially 3D mobile applications that include virtual anatomy animations supported by videos, YouTube videos and animations obtained from other social sharing sites, colorful 3D images and problemfocused learning have taken their place as the current methods used in anatomy education [3,4]. With the initiatives of anatomy educators to preserve traditional basic training methods such as dissection, there has been a face off between some clinical field educators that have transitioned to virtual simulative applications and conventional educators [2].

In this context, a process that gives rise to a necessity of updating the curriculum with various education and instruction methods has emerged. In addition to these methods, sharing of anatomy information via social networks today has started to be used by students as a learning method. For this reason, investigating the usage of existing anatomy learning methods and social platforms today for medical instruction purposes and shedding light on anatomy education have become a current need. For this purpose, we aimed to investigate publications that examine existing anatomy learning methods that are prevalently used by using metric methods. Especially bibliometric analysis (index criteria) is used in several fields to define the most significant studies [5]. This analysis method uses citation ranking to define the output with the largest intellectual effect in ranking articles.

The number of citations made to published articles is a reference in measuring the influence of the journal they are published in and assessing the capability of authors, and it is based on bibliometrics, which investigates such associations. Other important indicators that show the effect and quality of a journal are the journal impact factor (IF) which is based on citations and the h-index value provided by Web of Science (WoS), Scopus, Google Academics and Scimago Journal \& Country Rank (SJCR) [6, 7]. IF is a significant bibliometric indicator that needs to be used carefully as it is known to be a value in which several criteria play a role on the final value. JCR calculates the citations and publications of the last two years and returns the value of IF every September [12]. It is clearly seen that although it allows the evaluation of large data sets, keeping track of changes in citation databases over time and evaluating journal IF that vary from year to year creates measurement and technical problems for bibliometric analysis.

Altmetrics, which is a new web-based metric analysis method, has started to be used as a current method in assessing the impact analyses of publications on social media platforms [14]. This method that conducts an analysis as the Altmetric Attention Score (AAS) and Altmetric feedback was designed to make it easier to define how much and what type of interest a certain research output receives [15]. AAS is calculated by an automated algorithm created by the company Altmetric based on the weighted quantity of the online interest received by a research output. This algorithm that is used under the name of Altmetric Explorer (Altmetric, London, the United Kingdom) Score is a web-based application that can use some research output resources to present the online activities of publications and the most relevant discussion forms in a current sense [15]. While making calculations, three main factors are used to determine the weights: volume, sources and authors. The role of social media platforms in the publicity, dissemination and presentation of the medical literature was increased substantially in the last few years [17]. Altmetrics are advantageous in that they can reflect significant nonacademic effects and are visible before even academic citations occur, but they also have some disadvantages. At the beginning of these disadvantages, we can say that it is still not clear which general conclusion to draw from the altmetric analysis. In addition, data sparseness is an important disadvantage that makes altmetric analysis insufficient alone.

In this context, this study aimed to determine the relationship between bibliometric analysis on the number of citations of articles and journal IF values and Altmetric analysis (highest AAS and IF) which determine the social media usage score of studies in determining the quantitative impacts of methods in the field of anatomy in the world of medicine.

\section{METHODS}

In this study, WoS Core Collection database was used for bibliometric citation analysis and PubMed was used for other article information. PubMed data was used to see the total number of authors of the article and the type of article (eg Review etc.) and to evaluate the altmetric score on the "altmetric it / alt- 
metric.com" website. The WoS database was accessed (date of access: 15 January 2020) to determine the publications between 1975 and 2019 that contained the key phrase "Anatomy Education". As the WoS article database includes articles that have been published since 1975 on February 15, 2020, our access date, earlier articles could not be reached. As a result, 4356 articles related to the subject were obtained, and among these results, the 100 articles that received the most citations (T100) were subjected to bibliometric and altmetric score analysis. After writing "Anatomy education" in the "topic" criterion in WoS, there were articles outside the scope of anatomy education among the articles exhibited. For this reason, during the creation of the T100 article list, the Pubmed MESH terms were first examined to evaluate whether the studies were covered by the term "Anatomy education". In addition, the abstracts of the articles were read independently and carefully by the article researchers and the compatible articles with the subject of anatomy education were determined. The full texts of the articles, whose article summary was not clear enough, were also examined and carefully evaluated in such a way that bias was not allowed. At the end of these evaluations, articles that fall within the scope of "Anatomy education" are included in the study list, while other articles were excluded from the study as they are outside the scope of "Anatomy education". Subsequent articles were included within the scope to complement 100 in place of the articles that were omitted. For the studies published in the relevant field, name of the journal of publication, journal IF (2019 Journal Citation Reports (Clarivate Analytics)), year of publication, topic of article, type of article and sub-types were determined.

The AASs were obtained from the Altmetric.com website (https://www.altmetric.com/products/freetools/bookmarklet/) by using the "Altmetric it" function. Each color in altmetric feedback represents a different source from the social media sharing network [18]. As Altmetric Explorer is a licensed application, Altmetric it was used instead. In the color spectrum of feedback, blue represents Twitter, dark blue represents Facebook, yellow represent blogs, red represents news stories, orange represents patents, pink represents Google, and brown represents Wikipedia (Fig. 1). The study included original research articles, review articles, conference manuscripts and letters to the editor. Additionally, PubMed was utilized to obtain additional data for the study. This study did not need to be approved by an ethics committee, because it only conducted bibliometric and altmetric analyses on classical studies that have been published.

\section{Statistical Analysis}

To determine the relationships between the number of citations of the selected T100 anatomy education articles and AAS and between IF and AAS, descriptive statistics was revealed and evaluated, and Spearman's correlation analyses were carried out in SPSS package software.
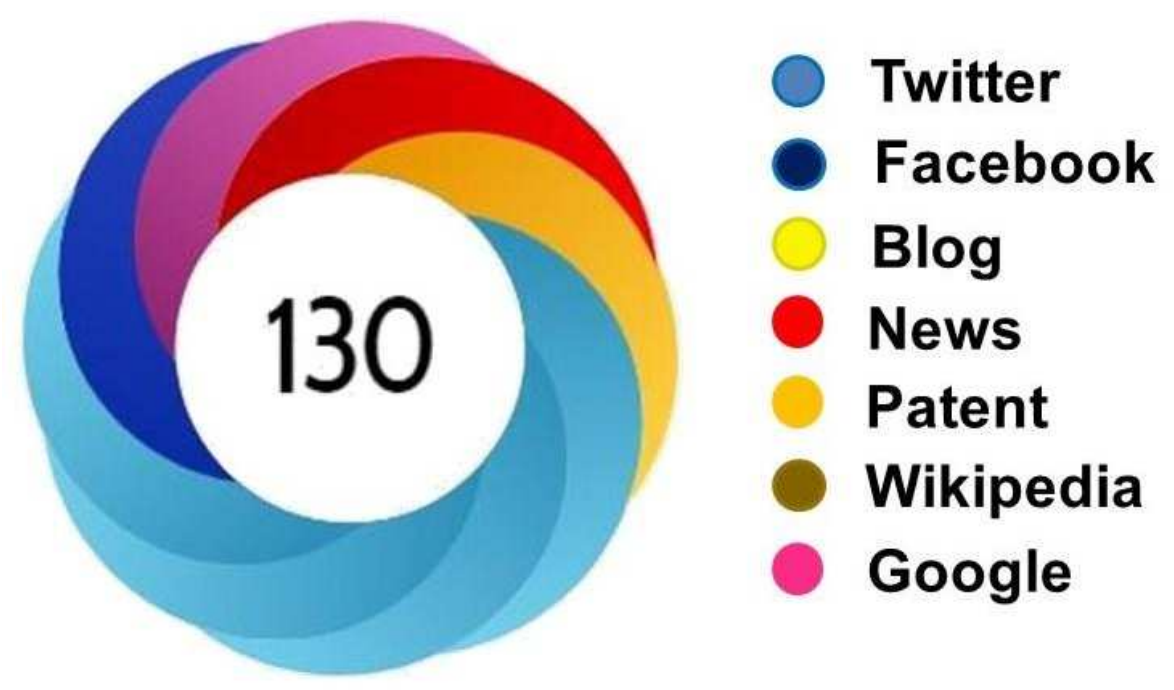

Fig. 1. Example of altmetric feedback scoring sources. 


\section{RESULTS}

In the search for publications in the period of 1975-2019 on WoS containing the key phrase "Anatomy education", 4356 articles were found. The T100 list on anatomy education shown in the literature was examined (Supplementary Table 1). In the list, the publications' numbers of citations, journals of publication, the highest numbers of publications based on years and AAS values were shown.

Sixty-eight of the T100 articles in this study were published in journals with an IF value of at least 2. According to Clarivate Analytics (2017), the average IF of 10 journals (Table 1 ) out of 26 journals in which at least two T100 articles were published was found, was 2.987 , and the average h-index value was 80 . The number of citations of the studies varied between 29 and 268. The study with the highest number of citations was published by McLachlan et al. [Suppl. Table 1 Rank 1] with the title "Teaching anatomy without cadavers, 2004". The one with the lowest number of citations was published by Baskaran et al. [Suppl. Table 1 Rank 100] with the title "Current applications and future perspectives of the use of 3D printing in anatomical training and neurosurgery".

Considering the publication years of the articles, it was determined that the time that passed since the article in the first place showed a change in favor of citations. Concerning the numbers of citations based on years, it was determined that the T100 publications almost did not receive any citations in 1998 and 1999, their numbers of citations continued to increase in the following years, and the highest number of citations was in 2019 (Fig. 2). Considering the distribution of the publications on the topic of anatomy education based on years, while there was no publication in the years 1997 and 1998 among the articles, the lowest number of publications were in 1996 and 2003 by one article each, while the highest numbers of publications were in 2007 and 2016 (Fig. 3).

The journal with the highest number of publications in this field was "Anatomical Sciences Education" with 39 publications, which was followed by "Clinical Anatomy" in the second place with 19 and "Medical Education" in the third place with 13 publications. On the field of anatomy education, the Journals Anatomical Record, ANZ Journal of Surgery, Computers Education and Surgical and Radiologic Anatomy had 2 publications each (Table 1).

Among the T100 articles with the highest numbers of citations, 86 were research articles, 6 were reviews, 5 were verbal presentations, and 3 were letters to the editor. The highest number of original articles published in the relevant field was 34 for the period of 2006-2010, the highest number of reviews was 4 for 2011-2015, and the highest number of verbal presentations was 2 for 2011-2015 (Table 2).

Considering the countries of publication of these articles, the United States of America (USA) had the first place with 37 publications, while the United Kingdom was in the second place with 18 publications, and Australia was in the third place with 15 ,

Table 1. Journals where the T100 articles with most citations were published

\begin{tabular}{cccccc}
\hline Rank & Journals & Amount & IF & H Index & Q Category \\
\hline 1 & Anatomical Sciences Education & 39 & 4.027 & 38 & Q1 \\
2 & Clinical Anatomy & 19 & 1.813 & 62 & Q2 \\
3 & Medical Education & 13 & 4.619 & 120 & Q1 \\
4 & Annals of Anatomy & 3 & 2.241 & 45 & Q2 \\
\hline 5 & Medical Teacher & 3 & 2.706 & 91 & Q1 \\
6 & Academic Radiology & 2 & 2.110 & 87 & Q1 \\
7 & Anatomical Record & 2 & 1.329 & 84 & Q2 \\
8 & Anz Journal of Surgery & 2 & 1.605 & 69 & Q3 \\
9 & Computers Education & 2 & 5.627 & 149 & Q1 \\
10 & Surgical and Radiologic Anatomy & 2 & 1.039 & 52 & Q2 \\
\hline
\end{tabular}

*Journals with 2 or more publications are listed. 


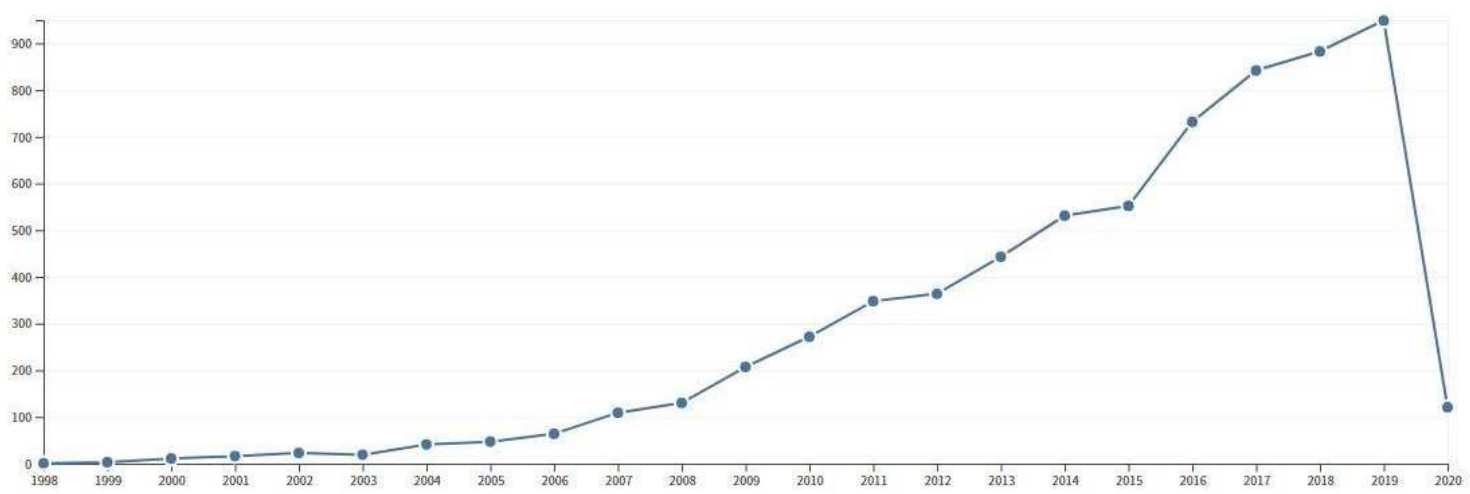

Fig. 2. Number of citations of publications in the field of anatomy education by years.

whereas $70 \%$ of the T100 articles were found to have been published by these three countries. The years with most publications for the USA and UK were 2006-2010, while Australia published more in the period of 2011-2015 in comparison to the other years (Table 2). From Turkey, only the article by Küçük. et al. [Suppl. Table 1 Rank 84] titled "Learning anatomy via mobile augmented reality: effects on achievement and cognitive load, 2016" was in this list.

When the types of research centers where the publications were made were examined, it was seen that these centers mostly operate in the fields of Education and educational research, Anatomy morphology and Health sciences. The highest number (68) and ratio $(48.83 \%)$ of the articles were in the field of education research, which naturally included studies on educa- tion. As seen in Table 3, it was observed that the number higher than 100 in the T100 list was caused by separate assessment of multidisciplinary studies and other fields.

The AAS values varied between 0 and 130. The article "The production of anatomical teaching resources using three-dimensional (3D) printing technology, 2014" (score 130) had the highest AAS score and most shares on Twitter. It was determined that it gained a fast scoring with social media shares although it was published on a close date. The T100 anatomy education articles' AAS, total number of citations, citations based on years, IF and h-index values are shown in Table 4. Accordingly, for the T100 articles ranked based on their total number of citations, the mean ASS was $5.29 \pm 40.44$, and the mean total num-

Total Publications

100 Analye

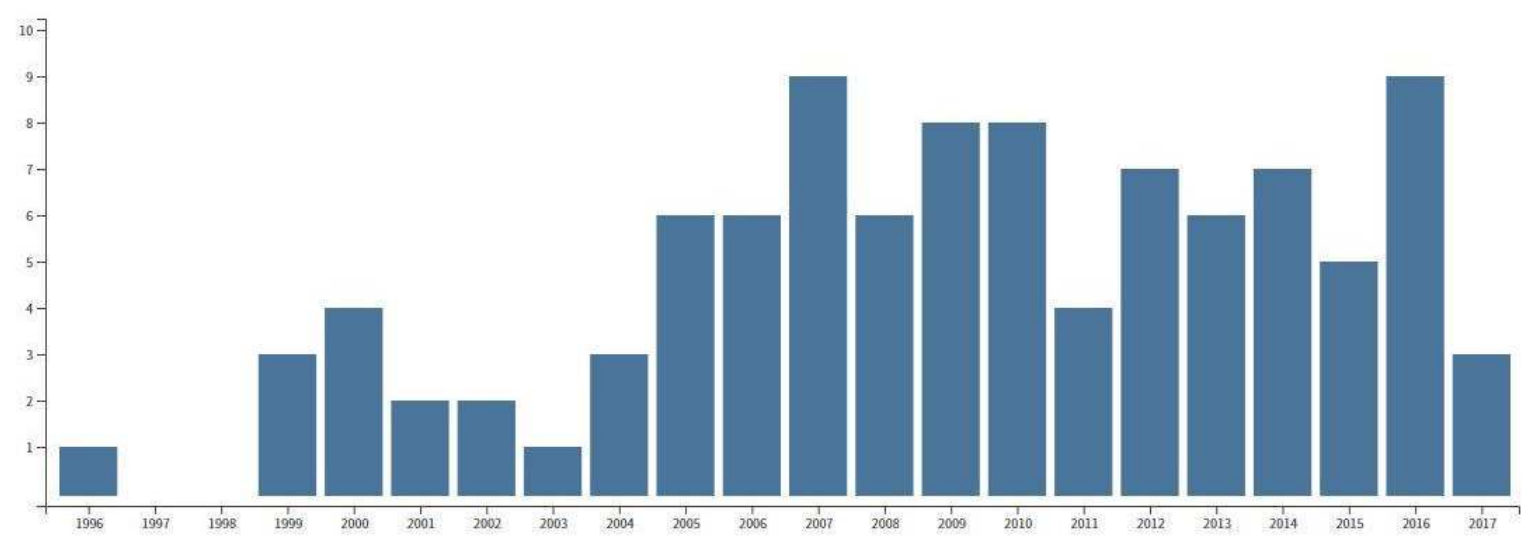

Fig. 3. Distribution of publications in the field of anatomy education by years. 
Table 2. Distribution of types of study and countries of the T100 articles with most citations based on years

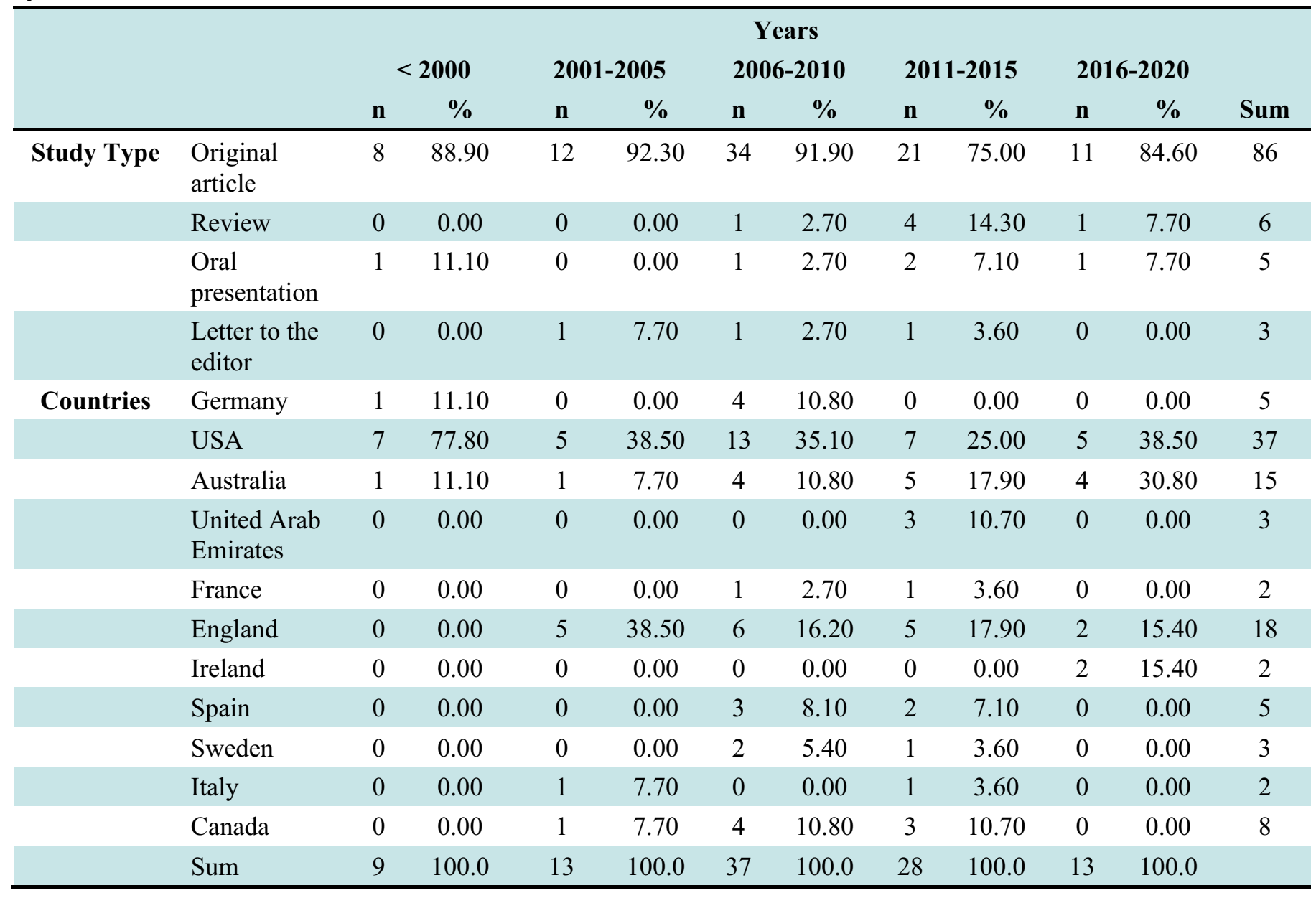

Table 3. Research centers where the T100 articles with most citations were conducted.

\begin{tabular}{lccc}
\hline Rank & Research type & $\mathbf{n}$ & $\mathbf{\%}$ \\
\hline 1 & Educational Research & 63 & 48.83 \\
2 & Morphological Anatomy & 27 & 20.93 \\
\hline 3 & Health Sciences & 18 & 13.95 \\
4 & Surgery & 6 & 4.65 \\
\hline 5 & Radiological Nuclear Medicine & 5 & 3.87 \\
6 & Computer Science & 3 & 2.32 \\
\hline 7 & Neuroscience, Neurology & 2 & 1.55 \\
\hline 8 & Acoustic & 1 & 0.78 \\
\hline 9 & General Internal Medicine & 1 & 0.78 \\
10 & Science Technology Other Subjects & 1 & 0.78 \\
11 & Social Sciences Other Subjects & 1 & 0.78 \\
12 & Veterinary Sciences & 1 & 0.78 \\
\hline
\end{tabular}




$\begin{aligned} & \text { Table 4. Number of citations, AAS and IF of the journals published the T100 anatomy } \\
& \text { education articles }\end{aligned}$
\begin{tabular}{lcccc} 
& Mean \pm SD & P25 & Median & P75 \\
\hline Altmetric score & $5.29 \pm 40.44$ & 0.00 & 0.00 & 3.00 \\
\hline Total citations & $66.84 \pm 1.23$ & 39.50 & 48.50 & 87.50 \\
\hline Number of citations per year & $6.33 \pm 35.73$ & 3.33 & 5.47 & 7.86 \\
\hline IF & $3.31 \pm 15.70$ & 1.81 & 4.03 & 4.03 \\
H Index & $65.75 \pm 3.87$ & 38.00 & 54.00 & 84.00 \\
\hline
\end{tabular}

ber of citations was $66.84 \pm 1.23$. The mean number of citations per year was $6.33 \pm 35.73$, the mean IF was $3.31 \pm 15.70$, and finally, the mean h-index was $65.75 \pm 3.87$ (Table 4).

Correlation analyses were conducted to determine the relationship between AAS and the number of citations based on years and h-index. While there was a positive moderate relationship between AAS and number of citations based on years $(r=0.428)$, AAS and $\mathrm{h}$-index had a negative weak relationship $(\mathrm{r}=-0.358)$. Likewise, there was a positive weak relationship between IF and h-index and number of citations based on years. There was no significant relationship between total number of citations and AAS (Table 5).

The variation of the instruction methods used in anatomy education was determined (Table 6). A broad scale of anatomy learning methods was determined to include current methods in the form of virtual and augmented reality applications, mobile technology applications in the form of ultrasonography, virtual simulators, laparoscopy and other radiological imaging methods, clinical anatomy instruction methods, outputs obtained by 3D printer technology, plastination, web-based interactive 3D visualization, enriched multimedia e-book applications, close peer, problemfocused instruction, clay models, and YouTube and social media sharing. Comparisons of education with and without cadavers had a significant place. While there was also an education method in the form of integrated multimodal-multidisciplinary and blended instruction method examinations, this method involved comparison of several models.

\section{DISCUSSION}

For the purpose of determining the effectiveness of methods that are used in the field of anatomy education, determining the online interest value and social media sharing scores of articles published on this topic and received the highest numbers of citations is highly

Table 5. Correlation analysis of the relationship between AAS and number of citations by year and h-index

\begin{tabular}{llcccc}
\hline & Total citations * & $\begin{array}{c}\text { Number of } \\
\text { citations per year }\end{array}$ & H Index & IF \\
\hline Altmetric scoring & $\mathrm{r}$ & -0.051 & 0.428 & -0.358 & $\mathbf{0 . 0 0 2}$ \\
& $\boldsymbol{p}$ value & 0.616 & $<\mathbf{0 . 0 0 1}$ & $<\mathbf{0 . 0 0 1}$ & 0.983 \\
\hline Total citations * & $\mathrm{r}$ & & 0.555 & 0.266 & 0.166 \\
& $p$ value & & $<\mathbf{0 . 0 0 1}$ & $\mathbf{0 . 0 0 9}$ & 0.106 \\
Number of citations & $\mathrm{r}$ & & -0.192 & 0.277 \\
per year & & & & 0.060 & $\mathbf{0 . 0 0 6}$ \\
& $\boldsymbol{p}$ value & & & & 0.123 \\
H Index & $\mathrm{r}$ & & & 0.231 \\
\hline
\end{tabular}

$\mathrm{r}=$ Spearman's correlation coefficient 


\begin{tabular}{|c|c|c|c|}
\hline Rank & Anatomy education methods & Classification & Amount \\
\hline 1 & Teaching with cadaver and dissection & $\mathrm{I}$ & 14 \\
\hline 2 & $\begin{array}{l}\text { Teaching with virtual reality, mobile augmented reality } \\
\text { and mobile technology }\end{array}$ & II & 18 \\
\hline 3 & 3D computer modeling and digital animated teaching & III & 10 \\
\hline 4 & $\begin{array}{l}\text { Anatomy teaching in clinical applications (Through } \\
\text { Ultrasound imaging, Laparoscope imaging, Surgical } \\
\text { simulators, Other radiological imaging techniques) }\end{array}$ & IV & 12 \\
\hline 5 & Computer assisted teaching & $\mathrm{V}$ & 10 \\
\hline 6 & $\begin{array}{l}\text { Integrated multimodal-multidisciplinary and blended } \\
\text { teaching }\end{array}$ & VI & 11 \\
\hline 7 & Teaching with Youtube & VII & 7 \\
\hline 8 & Teaching with 3D printer technology & VIII & 4 \\
\hline \multirow[t]{8}{*}{9} & Other: & IX & 14 \\
\hline & Problem-based teaching (3) & & \\
\hline & Near peer teaching (3) & & \\
\hline & Teaching with clay models (1) & & \\
\hline & Teaching with plastination (2) & & \\
\hline & Anatomy teaching with social media (1) & & \\
\hline & Teaching with enriched multimedia Ebook application (1) & & \\
\hline & Teaching with web-based interactive 3D visualization (3) & & \\
\hline
\end{tabular}

important in terms of determining trends towards the future. There are numerous studies and discussions carried out on suitable methods in obtaining academic information. Measuring the value and impact of studies and determining the trending topics are a significant criterion in determining the direction of studies. Considering that studies covering the comparative examinations of current practices used in anatomy education were conducted mostly in the period of 2007-2016, it was thought that this situation may be related to the date where especially virtual reality applications started to enter education. Virtual reality studies started to be carried out in 2006, and virtual reality became included in the education process as a technology-integrated instrument [19].

AAS assessment in our study revealed that the articles shared via social networks were rather on looking for answers to the question of "how to learn anatomy", and the effects of current practices such as "the contribution of 3D applications on anatomy edu- cation" were investigated. As Marsland and Lazarus [20] in 2018 stated in their work, information sharing via social media is more popular with students due to the continuous existence of technology throughout the lives of young people, and that it is an international academic platform for sharing knowledge and education research experiences among academicians. This situation showed that youths focused on studies on learning methods involving current techniques rather than conventional ones. When studies on learning with YouTube videos, which is another method used in anatomy education, is examined by bibliometric analysis, it was stated that YouTube videos would display low educational value in the case that they are not checked by member of academia [21-23]. In their study on the learning levels of students with anatomy education videos uploaded on YouTube, Jaffar [24] in 2012 emphasized that videos could be useful, but their effect on examination performance is weak, and students prefer to learn surface anatomy by cadavers and 
models. This idea was supported by the findings that YouTube videos and three-dimensional virtual reality videos have lower value in terms of education then dissections [25]. On the other hand, Winkellman [26] in 2007 reported that anatomy teaching with living beings and medical imaging methods is dominant over cadaver teaching. They added that these methods, which are especially advantageous for visual learners, are more compatible with clinical examination [26]. However, teaching about the 3D structure of the human body using 2D images is highly complicated. It is especially more difficult to perform volumetric examinations on the organs and structures that are desired to be imaged. For this reason, anatomic applications created in 3D are seen as an important method in making it easier to access structures by three-dimensional imaging.

Besides, teaching with cadavers should not be underestimated by relying solely on social media posts. Wilson et al. [27] in 2018 advocated the idea that the anatomical knowledge obtained by teaching with cadaver dissection remains in mind for a longer term in the temporal course in their studies where anatomy teaching methods were examined using meta-analysis method. However, they still recommended the examination and dissection of cadavers in the post-graduation surgical training of cadaver training.

When the social media sharing frequency of the article with the highest AAS (130) in our study, "The production of anatomical teaching resources using three dimensional (3D) printing technology," is examined, it was determined that it was shared via Twitter 30 times, Facebook 7 times, Google users 6 times, blogs 4 times and other networks 10 times. The highest number of shares made for the article with the second highest AAS, "Human cadaver vs. multimedia simulation: a study of student learning in anatomy," was again on Twitter. These findings confirm the comments of previous studies concluded that students and academicians have increased their interest in teaching styles with increased visual aspects. Regardless, as reported by Marsland and Lazarus [20], MD discussions around the anatomy teaching on twitter shows the need to develop potential educational resources to eliminate the difficulty in teaching and learning difficult areas in anatomy education.

It is highly important to comprehend basic anatomy in terms of being able to make the connections between anatomy knowledge and the clinic and integrate knowledge in surgical practices. For this reason, developing effective methods to teach anatomy is very important for medical practices. Since the Renaissance, cadaver dissection is still considered to be the most ideal and universal method for this purpose, and thus, it continues to be used as the building block of anatomy education $[1,28]$. Moreover, considering the increasing prevalence of robotic surgeries, it may be stated that application of cadaver surgery and virtual simulations together could be more ideal. Students are no longer satisfied with looking at the pictures of a textbook or observing from the corner of a crown surrounding a cadaver [29]. Therefore, it was thought that in could be sufficient in meeting educational needs for educators to plan a modern anatomy education that will integrate "new and old" approaches for these searches of students and put these plans into practice.

Altmetric scoring assesses an interest shown in a publication from a different perspective. While a relationship is expected between bibliometric and altmetric assessment, such a relationship could not be found in the analyses that were conducted. An interesting finding in our study was that the articles with the highest IF values did not receive more interest than the ones with low IF values. For example, journals like Computers Education, Medical Education and Anatomical Sciences Education that are included in the high-IF journal list or contributed to a large number of articles in the field of anatomy education were observed to be not in the highest rating in terms of Altmetric scoring. While it was expected for the relationship between altmetric scoring and number of citations based on years to be stronger, it was determined that this relationship was moderate. Due to the contribution of the public in addition to the scientific world to the scores of articles shared on social networks, it was considered that the main factor determining the direction is the attractiveness of the topic. eBizMBA Inc. [30] in 2020 listed the most popular social websites worldwide as Facebook, YouTube, Instagram and Twitter and stated Facebook as the most popular among these. The popular social networks in the list followed as WhatsApp, Pinterest, Reddit, Ask.fm, Tumblr, Flickr, SnapChat, VK, LinkedIn, Tagged and 
Meetup.

Although eBizMBA stated that Facebook is the most popular social network for sharing, it was seen that literature sharing was carried out more on Twitter. Marsland and Lazarus [20] in 2018 reported that an online community has formed on Twitter regarding literature sharing, but the impact of Twitter has not been completely demonstrated in anatomy instruction. They showed that Twitter could only be an instrument that strengthens the collaboration and communication of students with academicians, and social platforms may only have a useful impact under the appropriate guidance of academicians. Facebook is the most popular social media site visited daily by university students in integrating social media technologies into education. In their study that examined the usage activity of Facebook for the purpose of education in the field of anatomy, Jaffar [21] in 2014 reported that it has a natural potential in increasing learning in students, and it may be accepted as an instruction tool supportive of conventional education.

AASs are observed to provide new points of view in collecting scientific information. However, as the Altmetric system has started to collect data since the end of 2011, this method is only sensitive for later news. It may be considered that new articles may receive more AAS in time and lead to some incomplete interpretations. For this reason, by using bibliometric analysis, the weak aspect of the method was strengthened. Another important issue that should not be overlooked in AASs is social media policies of journals. Managers of some journals can develop planning digital scientific marketing practices for such social media metrics, which can influence the social media visibility of the journal and hence the journal's publications. This can be an important study topic that needs careful consideration. Even so it may be stated that AAS may be an indicator of the perceptions of the public on the dynamic field of science and medicine, and it will make it easier to determine the direction of studies in line with the high levels of interest by the public in time. It may also be considered as a catalyst that encourages reading scientific articles on a topic that is considered valuable by the public.

\section{CONCLUSION}

In this study, articles that examined instruction resources and strategies that are used in the discipline of anatomy were evaluated with analysis methods that allow looking from a broad perspective. The necessity of planning an anatomy education that comprehensively integrates conventional and modern approaches and the necessity of presenting these in practice were determined by the analyses. It may be stated that there is no strong evidence yet to suggest that social networks are strong anatomy instruction instruments. While the interest received by a scientific study in the literature is usually measured by the number of citations it receives, the interest received by it in the public is measured with parameters such as the number of news stories published on it and the speed of being shared on social platforms. Consequently, for being able to more comprehensively assess scientific research outputs, we recommend assessment of AAS and conventional metrics in combination.

\section{Authors' Contribution}

Study Conception: EP; Study Design: MD; Supervision: EP, MD; Funding: EP; Materials: EP, MD; Data Collection and/or Processing: EP, MD; Statistical Analysis and/or Data Interpretation: MK; Literature Review: MK, EP, MD; Manuscript Preparation: EP, MD, MK and Critical Review: EP, MD, MK.

\section{Conflict of interest}

The authors disclosed no conflict of interest during the preparation or publication of this manuscript.

\section{Financing}

The authors disclosed that they did not receive any grant during conduction or writing of this study.

Supplementary Table 1. Details of the T100 list on anatomy education

\begin{tabular}{lllcccccc}
\hline Rank & Article Title & Journal & Volume & Year & First Author & TCited* & $\begin{array}{c}\text { Average } \\
\text { Citations } \\
\text { per Year** }\end{array}$ & $\begin{array}{c}\text { Altmetric } \\
\text { Score }\end{array}$ \\
\hline $\mathbf{1}$ & $\begin{array}{l}\text { Teaching anatomy without } \\
\text { cadavers }\end{array}$ & Medical Education & 38 & 2004 & McLachlan, JC & 268 & 15.76 & 7 \\
\hline
\end{tabular}


Supplementary Table 1. Cotinued.

\begin{tabular}{|c|c|c|c|c|c|c|c|c|}
\hline Rank & Article Title & Journal & Volume & Year & First Author & TCited* & $\begin{array}{c}\text { Average } \\
\text { Citations } \\
\text { per Year** }\end{array}$ & $\begin{array}{c}\text { Altmetric } \\
\text { Score }\end{array}$ \\
\hline 2 & $\begin{array}{l}\text { The production of anatomical } \\
\text { teaching resources using three } \\
\text { dimensional (3D) printing } \\
\text { technology }\end{array}$ & $\begin{array}{l}\text { Anatomical } \\
\text { Sciences } \\
\text { Education }\end{array}$ & 7 & 2014 & $\begin{array}{l}\text { McMenamin, } \\
\text { PG }\end{array}$ & 174 & 24.86 & 130 \\
\hline 3 & $\begin{array}{l}\text { Anatomical dissection as a } \\
\text { teaching method in medical } \\
\text { school: a review of the } \\
\text { evidence }\end{array}$ & Medical Education & 41 & 2007 & $\begin{array}{c}\text { Winkelmann, } \\
\text { A }\end{array}$ & 174 & 12.43 & 4 \\
\hline 4 & $\begin{array}{l}\text { Can virtual reality improve } \\
\text { anatomy education? A } \\
\text { randomised controlled study } \\
\text { of a computer-generated } \\
\text { three-dimensional anatomical } \\
\text { ear model }\end{array}$ & Medical Education & 40 & 2006 & Nicholson, DT & 148 & 11.47 & 1 \\
\hline 5 & $\begin{array}{l}\text { Do we need dissection in an } \\
\text { integrated problem-based } \\
\text { learning medical course? } \\
\text { Perceptions of first- and } \\
\text { second-year students }\end{array}$ & $\begin{array}{l}\text { Surgical and } \\
\text { Radiologic } \\
\text { Anatomy }\end{array}$ & 29 & 2007 & Azer, SA & 148 & 10.57 & 3 \\
\hline 6 & $\begin{array}{l}\text { A pilot study of } \\
\text { comprehensive ultrasound } \\
\text { education at the Wayne state } \\
\text { university school of medicine } \\
\text { - A pioneer year review }\end{array}$ & $\begin{array}{l}\text { Journal of } \\
\text { Ultrasound in } \\
\text { Medicine }\end{array}$ & 27 & 2008 & Rao, S & 143 & 11.00 & 3 \\
\hline 7 & $\begin{array}{l}\text { "Let's Get Physical": } \\
\text { Advantages of a physical } \\
\text { model over 3D computer } \\
\text { models and textbooks in } \\
\text { learning imaging anatomy }\end{array}$ & $\begin{array}{l}\text { Anatomical } \\
\text { Sciences } \\
\text { Education }\end{array}$ & 6 & 2013 & Preece, D & 129 & 16.13 & 5 \\
\hline 8 & $\begin{array}{l}\text { The dissection course - } \\
\text { necessary and indispensable } \\
\text { for teaching anatomy to } \\
\text { medical students }\end{array}$ & $\begin{array}{l}\text { Annals of } \\
\text { Anatomy- } \\
\text { Anatomischer } \\
\text { Anzeiger }\end{array}$ & 190 & 2008 & Korf, HW & 129 & 9.92 & 0 \\
\hline 9 & $\begin{array}{l}\text { Near-peer teaching in } \\
\text { anatomy: an ppproach for } \\
\text { deeper learning }\end{array}$ & $\begin{array}{l}\text { Anatomical } \\
\text { Sciences } \\
\text { Education }\end{array}$ & 2 & 2009 & Evans, DJR & 125 & 10.42 & 4 \\
\hline 10 & $\begin{array}{l}\text { Web-based interactive 3D } \\
\text { visualization as a tool for } \\
\text { improved anatomy learning }\end{array}$ & $\begin{array}{l}\text { Anatomical } \\
\text { Sciences } \\
\text { Education }\end{array}$ & 2 & 2009 & Petersson, $\mathrm{H}$ & 121 & 10.08 & 0 \\
\hline 11 & $\begin{array}{l}\text { Mortui vivos decent? The } \\
\text { evolving purpose of human } \\
\text { dissection in medical } \\
\text { education }\end{array}$ & $\begin{array}{l}\text { Academic } \\
\text { Medicine }\end{array}$ & 75 & 2000 & Dyer, GSM & 121 & 5.76 & 0 \\
\hline 12 & $\begin{array}{l}\text { Survey of clinicians' attitudes } \\
\text { to the anatomical teaching and } \\
\text { knowledge of medical } \\
\text { students }\end{array}$ & Clinical Anatomy & 18 & 2005 & Waterston, SW & 118 & 7.38 & 0 \\
\hline 13 & $\begin{array}{l}\text { Perceptions of dissection by } \\
\text { students in one medical } \\
\text { school: beyond learning about } \\
\text { anatomy. A qualitative study }\end{array}$ & Medical Education & 39 & 2005 & Lempp, HK & 114 & 7.13 & 0 \\
\hline 14 & $\begin{array}{l}\text { Does problem-based learning } \\
\text { lead to deficiencies in basic } \\
\text { science knowledge? An } \\
\text { empirical case on anatomy }\end{array}$ & Medical Education & 37 & 2003 & Prince, KJAH & 114 & 6.33 & 0 \\
\hline 15 & $\begin{array}{l}\text { Reciprocal peer teaching: } \\
\text { Students teaching students in } \\
\text { the gross anatomy laboratory }\end{array}$ & Clinical Anatomy & 18 & 2005 & Krych, AJ & 109 & 6.81 & 0 \\
\hline
\end{tabular}


Supplementary Table 1. Continued.

\begin{tabular}{|c|c|c|c|c|c|c|c|c|}
\hline Rank & Article Title & Journal & Volume & Year & First Author & TCited* & $\begin{array}{c}\text { Average } \\
\text { Citations } \\
\text { per Year** }\end{array}$ & $\begin{array}{l}\text { Altmetric } \\
\text { Score }\end{array}$ \\
\hline 16 & $\begin{array}{l}\text { Effectiveness of using } \\
\text { blended learning strategies for } \\
\text { teaching and learning human } \\
\text { anatomy }\end{array}$ & Medical Education & 41 & 2007 & Pereira, JA & 108 & 7.71 & 0 \\
\hline 17 & $\begin{array}{l}\text { The relationships between } \\
\text { learning outcomes and } \\
\text { methods of teaching anatomy } \\
\text { as perceived by professional } \\
\text { anatomists }\end{array}$ & Clinical Anatomy & 21 & 2008 & Patel, K & 105 & 8.08 & 0 \\
\hline 18 & $\begin{array}{l}\text { Integrating professionalism in } \\
\text { early medical education: the } \\
\text { theory and application of } \\
\text { reflective practice in the } \\
\text { anatomy curriculum }\end{array}$ & Clinical Anatomy & 19 & 2006 & Lachman, $\mathrm{N}$ & 105 & 7.00 & 1 \\
\hline 19 & $\begin{array}{l}\text { The gross anatomy course: an } \\
\text { analysis of its importance }\end{array}$ & $\begin{array}{l}\text { Anatomical } \\
\text { Sciences } \\
\text { Education }\end{array}$ & 3 & 2010 & Boeckers, A & 99 & 9.00 & 0 \\
\hline 20 & $\begin{array}{l}\text { Modernization of an anatomy } \\
\text { class: from conceptualization } \\
\text { to implementation. A case for } \\
\text { integrated multimodal- } \\
\text { multidisciplinary teaching }\end{array}$ & $\begin{array}{l}\text { Anatomical } \\
\text { Sciences } \\
\text { Education }\end{array}$ & 5 & 2012 & Johnson, EO & 97 & 10.78 & 2 \\
\hline 21 & $\begin{array}{l}\text { YouTube: an emerging tool in } \\
\text { anatomy education }\end{array}$ & $\begin{array}{l}\text { Anatomical } \\
\text { Sciences } \\
\text { Education }\end{array}$ & 5 & 2012 & Jaffar, AA & 96 & 10.67 & 15 \\
\hline 22 & $\begin{array}{l}\text { Medical students' learning of } \\
\text { anatomy: memorisation, } \\
\text { understanding and } \\
\text { visualisation }\end{array}$ & Medical Education & 41 & 2007 & Pandey, P & 94 & 6.71 & \\
\hline 23 & $\begin{array}{l}\text { Evaluation of computer-aided } \\
\text { instruction in a gross anatomy } \\
\text { course: a six-year study }\end{array}$ & $\begin{array}{l}\text { Anatomical } \\
\text { Sciences } \\
\text { Education }\end{array}$ & 2 & 2009 & McNulty, JA & 92 & 7.67 & \\
\hline 24 & $\begin{array}{l}\text { Use of 3D printed models in } \\
\text { medical education: a } \\
\text { randomized control trial } \\
\text { comparing 3D prints versus } \\
\text { cadaveric materials for } \\
\text { learning external cardiac } \\
\text { anatomy }\end{array}$ & $\begin{array}{l}\text { Anatomical } \\
\text { Sciences } \\
\text { Education }\end{array}$ & 15 & 2016 & Lim, KHA & 89 & 17.80 & 12 \\
\hline 25 & $\begin{array}{l}\text { A novel three-dimensional } \\
\text { tool for teaching }\end{array}$ & $\begin{array}{l}\text { Human } \\
\text { Neuroanatomy. }\end{array}$ & 3 & 2010 & Estevez, ME & 88 & 8.00 & 7 \\
\hline 26 & $\begin{array}{l}\text { Virtual reality and brain } \\
\text { anatomy: a randomised trial } \\
\text { of e-learning instructional } \\
\text { designs }\end{array}$ & Medical Education & 41 & 2007 & Levinson, AJ & 87 & 6.21 & 0 \\
\hline 27 & $\begin{array}{l}\text { Teaching anatomy: cadavers } \\
\text { vs. computers? }\end{array}$ & $\begin{array}{l}\text { Annals of } \\
\text { Anatomy- } \\
\text { Anatomischer } \\
\text { Anzeiger }\end{array}$ & 188 & 2006 & Biasutto, SN & 87 & 5.80 & 0 \\
\hline 28 & $\begin{array}{l}\text { Using multimedia and } \\
\text { Web3D to enhance anatomy } \\
\text { teaching. }\end{array}$ & $\begin{array}{l}\text { Computers \& } \\
\text { Education }\end{array}$ & 49 & 2007 & Brenton, $\mathrm{H}$ & 84 & 6.00 & 0 \\
\hline 29 & $\begin{array}{l}\text { Best teaching practices in } \\
\text { anatomy education: a critical } \\
\text { review. }\end{array}$ & $\begin{array}{l}\text { Annals of } \\
\text { Anatomy- } \\
\text { Anatomischer } \\
\text { Anzeiger }\end{array}$ & 208 & 2016 & Estai, M & 83 & 16.60 & 0 \\
\hline
\end{tabular}


Supplementary Table 1. Continued.

\begin{tabular}{|c|c|c|c|c|c|c|c|c|}
\hline Rank & Article Title & Journal & Volume & Year & First Author & TCited* & $\begin{array}{c}\text { Average } \\
\text { Citations } \\
\text { per Year** }\end{array}$ & $\begin{array}{l}\text { Altmetric } \\
\text { Score }\end{array}$ \\
\hline 30 & $\begin{array}{l}\text { Computer-aided learning: an } \\
\text { overvalued educational } \\
\text { resource? }\end{array}$ & Medical Education & 33 & 1999 & Devitt, $\mathrm{P}$ & 76 & 3.45 & 0 \\
\hline 31 & $\begin{array}{l}\text { Restructuring a basic science } \\
\text { course for core competencies: } \\
\text { an example from anatomy } \\
\text { teaching }\end{array}$ & Medical Teacher & 31 & 2009 & Gregory, JK & 75 & 6.25 & 0 \\
\hline 32 & $\begin{array}{l}\text { Teaching and learning gross } \\
\text { anatomy: dissection, } \\
\text { prosection, or "both of the } \\
\text { above?" }\end{array}$ & Clinical Anatomy & 12 & 1999 & Dinsmore, $\mathrm{CE}$ & 73 & 3.32 & 0 \\
\hline 33 & $\begin{array}{l}\text { Anatomical dissection: Why } \\
\text { are we cutting it out? } \\
\text { Dissection in undergraduate } \\
\text { teaching. }\end{array}$ & $\begin{array}{l}\text { ANZ Journal of } \\
\text { Surgery }\end{array}$ & 31 & 2002 & Parker, LM & 71 & 3.74 & 2 \\
\hline 34 & $\begin{array}{l}\text { Ultrasound anatomy: a } \\
\text { practical teaching system in } \\
\text { human gross anatomy }\end{array}$ & Medical Edication & 30 & 1996 & $\begin{array}{l}\text { Teichgraber, } \\
\text { UKM }\end{array}$ & 71 & 2.84 & 0 \\
\hline 35 & $\begin{array}{l}\text { The relative effectiveness of } \\
\text { computer-based and } \\
\text { traditional resources for } \\
\text { education in anatomy }\end{array}$ & $\begin{array}{l}\text { Anatomical } \\
\text { Sciences } \\
\text { Education }\end{array}$ & 6 & 2013 & Khot, Z & 69 & 8.63 & 3 \\
\hline 36 & $\begin{array}{l}\text { Integration of ultrasound in } \\
\text { the education programme in } \\
\text { anatomy }\end{array}$ & Medical Edication & 11 & 2005 & $\begin{array}{l}\text { Tshibwabwa, } \\
\text { ET }\end{array}$ & 69 & 4.31 & 0 \\
\hline 37 & $\begin{array}{l}\text { Importance of dissection in } \\
\text { learning anatomy: personal } \\
\text { dissection versus peer } \\
\text { teaching }\end{array}$ & Clinical Anatomy & 15 & 2002 & Johnson, JH & 67 & 3.53 & 0 \\
\hline 38 & $\begin{array}{l}\text { Dissection as a modulator of } \\
\text { emotional attitudes and } \\
\text { reactions of future health } \\
\text { professionals }\end{array}$ & Medical Edication & 42 & 2008 & Arraez, A & 66 & 5.08 & 0 \\
\hline 39 & $\begin{array}{l}\text { Advanced 3D visualization in } \\
\text { student-centred medical } \\
\text { education }\end{array}$ & Medical Teacher & 30 & 2008 & Silen, C & 62 & 4.77 & 0 \\
\hline 40 & $\begin{array}{l}\text { The role of three-dimensional } \\
\text { information in health care and } \\
\text { medical education: the } \\
\text { implications for anatomy and } \\
\text { dissection }\end{array}$ & Clinical Anatomy & 13 & 2000 & Marks, SC & 62 & 2.95 & 0 \\
\hline 41 & $\begin{array}{l}\text { Complementing anatomy } \\
\text { education using three- } \\
\text { dimensional anatomy mobile } \\
\text { soware applications on tablet } \\
\text { computers }\end{array}$ & Clinical Anatomy & 27 & 2014 & Lewis, TL & 60 & 8.57 & 7 \\
\hline 42 & $\begin{array}{l}\text { Medical students' approaches } \\
\text { to learning anatomy: students' } \\
\text { experiences and relations to } \\
\text { the learning environment. }\end{array}$ & Clinical Anatomy & 23 & 2010 & Smith, CF & 55 & 5.00 & 1 \\
\hline 43 & $\begin{array}{l}\text { Anatomy education for the } \\
\text { YouTube generation }\end{array}$ & $\begin{array}{l}\text { Anatomical } \\
\text { Sciences } \\
\text { Education }\end{array}$ & 9 & 2016 & Barry, DS & 54 & 10.80 & 15 \\
\hline 44 & $\begin{array}{l}\text { Evaluation of a surgical } \\
\text { simulator for learning clinical } \\
\text { anatomy }\end{array}$ & Medical Education & 38 & 2004 & Hariri, S & 53 & 3.12 & 0 \\
\hline
\end{tabular}


Supplementary Table 1. Continued.

\begin{tabular}{|c|c|c|c|c|c|c|c|c|}
\hline Rank & Article Title & Journal & Volume & Year & First Author & TCited* & $\begin{array}{c}\text { Average } \\
\text { Citations } \\
\text { per Year** }\end{array}$ & $\begin{array}{l}\text { Altmetric } \\
\text { Score }\end{array}$ \\
\hline 45 & $\begin{array}{l}\text { Ultrasound and cadaveric } \\
\text { prosections as methods for } \\
\text { teaching cardiac anatomy: a } \\
\text { comparative study }\end{array}$ & $\begin{array}{l}\text { Anatomical } \\
\text { Sciences } \\
\text { Education. }\end{array}$ & 5 & 2012 & Griksaitis, MJ & 52 & 5.78 & 3 \\
\hline 46 & $\begin{array}{l}\text { Mirracle: an augmented } \\
\text { reality magic mirror system } \\
\text { for anatomy education }\end{array}$ & $\begin{array}{l}\text { IEE Virtual } \\
\text { Reality } \\
\text { Conference }\end{array}$ & $\ldots$ & 2012 & Blum, T & 52 & 5.78 & 0 \\
\hline 47 & $\begin{array}{l}\text { The value of teaching } \\
\text { sectional anatomy to improve } \\
\text { CT scan interpretation }\end{array}$ & Clinical Anatomy. & 14 & 2001 & De Barros, N & 52 & 2.60 & 0 \\
\hline 48 & $\begin{array}{l}\text { From Chalkboard, slides, and } \\
\text { paper to e-learning: how } \\
\text { computing technologies have } \\
\text { transformed anatomical } \\
\text { sciences education }\end{array}$ & $\begin{array}{l}\text { Anatomical } \\
\text { Sciences } \\
\text { Education. }\end{array}$ & 9 & 2016 & Trelease, RB & 49 & 9.80 & 5 \\
\hline 49 & $\begin{array}{l}\text { Back to the future: teaching } \\
\text { anatomy by whole-body } \\
\text { dissection }\end{array}$ & $\begin{array}{l}\text { Medical Journal of } \\
\text { Australia. }\end{array}$ & 193 & 2010 & Ramsey, G & 49 & 4.45 & 0 \\
\hline 50 & $\begin{array}{l}\text { Learning of cross-sectional } \\
\text { amatomy using clay Models }\end{array}$ & $\begin{array}{l}\text { Anatomical } \\
\text { Sciences } \\
\text { Education }\end{array}$ & 2 & 2009 & $\mathrm{Oh}, \mathrm{CS}$ & 49 & 4.08 & 1 \\
\hline 51 & $\begin{array}{l}\text { Can "YouTube" help students } \\
\text { in learning surface anatomy? }\end{array}$ & $\begin{array}{l}\text { Surgical and } \\
\text { Radiologic } \\
\text { Anatomy }\end{array}$ & 34 & 2012 & Azer, SA & 48 & 5.33 & 3 \\
\hline 52 & $\begin{array}{l}\text { Computer visualizations: } \\
\text { factors that influence spatial } \\
\text { anatomy comprehension }\end{array}$ & $\begin{array}{l}\text { Anatomical } \\
\text { Sciences } \\
\text { Education }\end{array}$ & 5 & 2012 & Ngan, $\mathrm{N}$ & 48 & 5.33 & 0 \\
\hline 53 & $\begin{array}{l}\text { A meta-analysis of the } \\
\text { educational effectiveness of } \\
\text { three-dimensional } \\
\text { visualization technologies in } \\
\text { teaching anatomy }\end{array}$ & $\begin{array}{l}\text { Anatomical } \\
\text { Sciences } \\
\text { Education }\end{array}$ & 8 & 2015 & Yammine, $\mathrm{K}$ & 46 & 7.67 & 0 \\
\hline 54 & $\begin{array}{l}\text { The application of } 3 \mathrm{D} \text { printing } \\
\text { in anatomy education }\end{array}$ & $\begin{array}{l}\text { Medical Education } \\
\text { Online }\end{array}$ & 20 & 2015 & $\begin{array}{l}\text { AbouHashem, } \\
\text { Y }\end{array}$ & 46 & 7.67 & 6 \\
\hline 55 & $\begin{array}{l}\text { Virtual reality anatomy: is it } \\
\text { comparable with traditional } \\
\text { methods in the teaching of } \\
\text { human forearm } \\
\text { musculoskeletal anatomy? }\end{array}$ & $\begin{array}{l}\text { Anatomical } \\
\text { Sciences } \\
\text { Education }\end{array}$ & 4 & 2011 & Codd, AM & 46 & 4.60 & 7 \\
\hline 56 & $\begin{array}{l}\text { Problem-based learning: is } \\
\text { anatomy a casualty? }\end{array}$ & $\begin{array}{l}\text { Plastic and } \\
\text { Reconstrictive } \\
\text { Surgery }\end{array}$ & 3 & 2005 & Hinduja, K & 46 & 2.88 & 0 \\
\hline 57 & $\begin{array}{l}\text { Progress and perspectives in } \\
\text { computational neuroanatomy }\end{array}$ & $\begin{array}{l}\text { Anatomical } \\
\text { Record }\end{array}$ & 257 & 1999 & Ascoli, GA & 46 & 2.09 & 3 \\
\hline 58 & $\begin{array}{l}\text { Experimental evidence for } \\
\text { improved neuroimaging } \\
\text { interpretation using three- } \\
\text { dimensional graphic models }\end{array}$ & $\begin{array}{l}\text { Anatomical } \\
\text { Sciences } \\
\text { Education }\end{array}$ & 5 & 2012 & Ruisoto, $\mathrm{P}$ & 45 & 5.00 & 0 \\
\hline 59 & $\begin{array}{l}\text { How useful is plastination in } \\
\text { learning anatomy? }\end{array}$ & $\begin{array}{l}\text { Journal of } \\
\text { Veterinary } \\
\text { Medical Edcuation }\end{array}$ & 34 & 2007 & Latorre, RM & 45 & 3.21 & 3 \\
\hline 60 & $\begin{array}{l}\text { Using QuickTime virtual } \\
\text { reality objects in computer- } \\
\text { assisted instruction of gross } \\
\text { anatomy: Yorick - the VR } \\
\text { skull }\end{array}$ & Clinical Anatomy & 13 & 2000 & Nieder, GL & 45 & 2.14 & 0 \\
\hline
\end{tabular}


Supplementary Table 1 . Continued.

\begin{tabular}{|c|c|c|c|c|c|c|c|c|}
\hline Rank & Article Title & Journal & Volume & Year & First Author & TCited* & $\begin{array}{l}\text { Average } \\
\text { Citations } \\
\text { per Year** }\end{array}$ & $\begin{array}{l}\text { Altmetric } \\
\text { Score }\end{array}$ \\
\hline 61 & $\begin{array}{l}\text { Tendons, ligaments, and } \\
\text { capsule of the rotator cuff. } \\
\text { Gross and microscopic } \\
\text { anatomy }\end{array}$ & $\begin{array}{l}\text { Anatomical } \\
\text { Sciences } \\
\text { Education }\end{array}$ & 7 & 2014 & Clark JM & 44 & 6.29 & 0 \\
\hline 62 & $\begin{array}{l}\text { Building the dody: active } \\
\text { learning laboratories that } \\
\text { emphasize practical aspects of } \\
\text { anatomy and integration with } \\
\text { radiology }\end{array}$ & $\begin{array}{l}\text { Anatomical } \\
\text { Sciences } \\
\text { Education }\end{array}$ & 3 & 2010 & Zumwalt, AC & 44 & 4.00 & 0 \\
\hline 63 & $\begin{array}{l}\text { The effectiveness of virtual } \\
\text { and augmented reality in } \\
\text { health sciences and medical } \\
\text { anatomy }\end{array}$ & $\begin{array}{l}\text { Anatomical } \\
\text { Sciences } \\
\text { Education. }\end{array}$ & 10 & 2017 & Moro, $\mathrm{C}$ & 43 & 10.75 & 34 \\
\hline 64 & $\begin{array}{l}\text { Teaching anatomy in the XXI } \\
\text { century: new aspects and } \\
\text { pitfalls }\end{array}$ & $\begin{array}{l}\text { Scientific World } \\
\text { Journal }\end{array}$ & --- & 2013 & Papa, V & 43 & 5.38 & 1 \\
\hline 65 & $\begin{array}{l}\text { Teaching anatomy with } \\
\text { surgeons' tools: use of the } \\
\text { laparoscope in clinical } \\
\text { anatomy }\end{array}$ & Clinical Anatomy & 14 & 2001 & $\begin{array}{l}\text { Fitzpatrick, } \\
\text { CM }\end{array}$ & 43 & 2.15 & 0 \\
\hline 66 & $\begin{array}{l}\text { Social media and anatomy } \\
\text { education: using Twitter to } \\
\text { enhance the student learning } \\
\text { experience in anatomy }\end{array}$ & $\begin{array}{l}\text { Anatomical } \\
\text { Sciences } \\
\text { Education }\end{array}$ & 9 & 2016 & Hennessy, CM & 42 & 8.40 & 47 \\
\hline 67 & $\begin{array}{l}\text { The impact of alternating } \\
\text { dissection on student } \\
\text { performance in a medical } \\
\text { anatomy course: are } \\
\text { dissection videos an elective } \\
\text { substitute for actual } \\
\text { dissection? }\end{array}$ & Clinical Anatomy & 20 & 2007 & Granger, NA & 42 & 3.00 & 1 \\
\hline 68 & $\begin{array}{l}\text { Virtual anatomy: an } \\
\text { anatomist's playground }\end{array}$ & Clinical Anatomy & 19 & 2006 & Spitzer, VM & 42 & 2.80 & 0 \\
\hline 69 & $\begin{array}{l}\text { Building virtual models by } \\
\text { postprocessing radiology } \\
\text { images: a guide for anatomy } \\
\text { faculty }\end{array}$ & $\begin{array}{l}\text { Anatomical } \\
\text { Sciences } \\
\text { Education. }\end{array}$ & 3 & 2010 & Tam, M & 40 & 3.64 & 0 \\
\hline 70 & $\begin{array}{l}\text { Virtual temporal bone: an } \\
\text { interactive } 3 \text {-dimensional } \\
\text { learning aid for cranial base } \\
\text { surgery }\end{array}$ & Neurosurgery & 64 & 2009 & Kockro, RA & 40 & 3.33 & 3 \\
\hline 71 & $\begin{array}{l}\text { The poor, the black, and the } \\
\text { marginalized as the source of } \\
\text { cadavers in United States } \\
\text { anatomical education }\end{array}$ & Clinical Anatomy & 20 & 2007 & Halperin, EC & 40 & 2.86 & 22 \\
\hline 72 & $\begin{array}{l}\text { Teaching methods in anatomy } \\
\text { courses in North American } \\
\text { medical schools: the role of } \\
\text { radiology }\end{array}$ & $\begin{array}{l}\text { Academis } \\
\text { Radiology }\end{array}$ & 13 & 2006 & Ganske, I & 40 & 2.67 & 0 \\
\hline 73 & $\begin{array}{l}\text { Anatomy instruction in } \\
\text { medical schools: connecting } \\
\text { the past and the future }\end{array}$ & $\begin{array}{l}\text { Advances in } \\
\text { Health Sciences } \\
\text { Education }\end{array}$ & 11 & 2006 & Leung, KK & 40 & 2.67 & 0 \\
\hline 74 & $\begin{array}{l}\text { Evaluation of computer-aided } \\
\text { instruction in the medical } \\
\text { gross anatomy curriculum }\end{array}$ & Clinical Anatomy & 17 & 2004 & McNulty, JA & 40 & 2.35 & 0 \\
\hline
\end{tabular}


Supplementary Table 1. Continued.

\begin{tabular}{|c|c|c|c|c|c|c|c|c|}
\hline Rank & Article Title & Journal & Volume & Year & First Author & TCited* & $\begin{array}{c}\text { Average } \\
\text { Citations } \\
\text { per Year } * * \\
\end{array}$ & $\begin{array}{l}\text { Altmetric } \\
\text { Score }\end{array}$ \\
\hline 75 & $\begin{array}{l}\text { Animated PowerPoint as a } \\
\text { tool to teach anatomy }\end{array}$ & $\begin{array}{l}\text { Conference: } \\
\text { Annual Meeting of } \\
\text { the AAA held at } \\
\text { the EB }\end{array}$ & 261 & 2000 & $\begin{array}{l}\text { Carmichael, } \\
\text { SW }\end{array}$ & 40 & 1.90 & 0 \\
\hline 76 & $\begin{array}{l}\text { Effectiveness of three- } \\
\text { dimensional digital animation } \\
\text { in teaching human anatomy in } \\
\text { an authentic classroom } \\
\text { context }\end{array}$ & $\begin{array}{l}\text { Anatomical } \\
\text { Sciences } \\
\text { Education }\end{array}$ & 3 & 2014 & Hoyek, N & 39 & 5.57 & 3 \\
\hline 77 & $\begin{array}{l}\text { Undergraduate perspectives } \\
\text { on the teaching and learning } \\
\text { of anatomy }\end{array}$ & $\begin{array}{l}\text { Anz Journal of } \\
\text { Surgery }\end{array}$ & 79 & 2009 & Mitchell, R & 39 & 3.25 & 0 \\
\hline 78 & $\begin{array}{l}\text { Direct manipulation is better } \\
\text { than passive viewing for } \\
\text { learning anatomy in a three- } \\
\text { dimensional virtual reality } \\
\text { environment }\end{array}$ & $\begin{array}{l}\text { Computers \& } \\
\text { Education }\end{array}$ & 247 & 2017 & Jang, S & 38 & 9.50 & 10 \\
\hline 79 & $\begin{array}{l}\text { How useful is YouTube in } \\
\text { learning heart anatomy? }\end{array}$ & $\begin{array}{l}\text { Anatomical } \\
\text { Sciences } \\
\text { Education }\end{array}$ & 7 & 2014 & Raikos, A & 38 & 5.43 & 35 \\
\hline 80 & $\begin{array}{l}\text { Cadaveric dissection as an } \\
\text { educational tool for } \\
\text { anatomical sciences in the } \\
21 \text { st century }\end{array}$ & $\begin{array}{l}\text { Anatomical } \\
\text { Sciences } \\
\text { Education }\end{array}$ & 10 & 2017 & Ghosh, SK & 37 & 9.25 & 7 \\
\hline 81 & $\begin{array}{l}\text { A change in paradigm: giving } \\
\text { back identity to donors in the } \\
\text { anatomy laboratory }\end{array}$ & Clinical Anatomy & 26 & 2013 & Talarico, EF & 37 & 4.63 & 0 \\
\hline 82 & $\begin{array}{l}\text { A head in virtual reality: } \\
\text { development of a dynamic } \\
\text { head and neck model }\end{array}$ & $\begin{array}{l}\text { Anatomical } \\
\text { Sciences } \\
\text { Education }\end{array}$ & 2 & 2009 & Nguyen, $\mathrm{N}$ & 37 & 3.08 & 0 \\
\hline 83 & $\begin{array}{l}\text { Transforming clinical imaging } \\
\text { data for virtual reality } \\
\text { learning objects. }\end{array}$ & $\begin{array}{l}\text { Anatomical } \\
\text { Sciences } \\
\text { Education }\end{array}$ & 1 & 2008 & Trelease, RB & 37 & 2.85 & 0 \\
\hline 84 & $\begin{array}{l}\text { Learning anatomy via mobile } \\
\text { augmented reality: effects on } \\
\text { achievement and cognitive } \\
\text { load }\end{array}$ & $\begin{array}{l}\text { Anatomical } \\
\text { Sciences } \\
\text { Education }\end{array}$ & 9 & 2016 & Küçük, S & 36 & 7.20 & 1 \\
\hline 85 & $\begin{array}{l}\text { Perceptions of a mobile } \\
\text { technology on learning } \\
\text { strategies in the anatomy } \\
\text { laboratory }\end{array}$ & $\begin{array}{l}\text { Anatomical } \\
\text { Sciences } \\
\text { Education }\end{array}$ & 6 & 2013 & Mayfield, CH & 36 & 4.50 & 1 \\
\hline 86 & $\begin{array}{l}\text { Use of plastinated prosections } \\
\text { for teaching anatomy-The } \\
\text { view of medical students on } \\
\text { the value of this learning } \\
\text { resource }\end{array}$ & Clinical Anatomy & 24 & 2011 & $\begin{array}{l}\text { Fruhstorfer, } \\
\text { BH }\end{array}$ & 36 & 3.60 & 1 \\
\hline 87 & $\begin{array}{l}\text { Explorable three-dimensional } \\
\text { digital model of the female } \\
\text { pelvis, pelvic contents, and } \\
\text { perineum for anatomical } \\
\text { education }\end{array}$ & $\begin{array}{l}\text { Anatomical } \\
\text { Sciences } \\
\text { Education }\end{array}$ & 3 & 2010 & Sergovich, A & 36 & 3.27 & 0 \\
\hline 88 & $\begin{array}{l}\text { Developing medical students } \\
\text { as teachers: an anatomy-based } \\
\text { student-as-teacher program } \\
\text { with emphasis on core } \\
\text { teaching competencies }\end{array}$ & $\begin{array}{l}\text { Anatomical } \\
\text { Sciences } \\
\text { Education }\end{array}$ & 6 & 2013 & Erie, AJ & 35 & 4.38 & 34 \\
\hline
\end{tabular}


Supplementary Table 1. Continued.

\begin{tabular}{|c|c|c|c|c|c|c|c|c|}
\hline Rank & Article Title & Journal & Volume & Year & First Author & TCited* & $\begin{array}{c}\text { Average } \\
\text { Citations } \\
\text { per Year** }\end{array}$ & $\begin{array}{l}\text { Altmetric } \\
\text { Score }\end{array}$ \\
\hline 89 & $\begin{array}{l}\text { Human cadavers vs. } \\
\text { multimedia simulation: a } \\
\text { study of student learning in } \\
\text { anatomy }\end{array}$ & $\begin{array}{l}\text { Anatomical } \\
\text { Sciences } \\
\text { Education }\end{array}$ & 7 & 2014 & Saltarelli, AJ & 34 & 4.86 & 52 \\
\hline 90 & $\begin{array}{l}\text { An enriched multimedia } \\
\text { eBook application to facilitate } \\
\text { learning of anatomy }\end{array}$ & $\begin{array}{l}\text { Anatomical } \\
\text { Sciences } \\
\text { Education }\end{array}$ & 7 & 2014 & Stirling, A & 34 & 4.86 & 14 \\
\hline 91 & $\begin{array}{l}\text { Enhancement of temporal } \\
\text { bone anatomy learning with } \\
\text { computer 3D rendered } \\
\text { imaging sowares }\end{array}$ & Medical Teacher & 332 & 2010 & Venail, F & 34 & 3.09 & 0 \\
\hline 92 & $\begin{array}{l}\text { How spatial abilities and } \\
\text { dynamic visualizations } \\
\text { interplay when learning } \\
\text { functional anatomy with 3D } \\
\text { anatomical models }\end{array}$ & $\begin{array}{l}\text { Anatomical } \\
\text { Sciences } \\
\text { Education }\end{array}$ & 8 & 2015 & Berney, S & 33 & 5.50 & 3 \\
\hline 93 & $\begin{array}{l}\text { ARBOOK: Development and } \\
\text { assessment of a tool based on } \\
\text { augmented reality for } \\
\text { anatomy }\end{array}$ & $\begin{array}{l}\text { Journal of Science } \\
\text { Education and } \\
\text { Technology }\end{array}$ & 24 & 2015 & Ferrer, TJ & 33 & 5.50 & 1 \\
\hline 94 & $\begin{array}{l}\text { Fabrication and assessment of } \\
\text { 3D printed anatomical models } \\
\text { of the lower limb for } \\
\text { anatomical teaching and } \\
\text { femoral vessel access training } \\
\text { in medicine }\end{array}$ & $\begin{array}{l}\text { Anatomical } \\
\text { Sciences } \\
\text { Education }\end{array}$ & 9 & 2016 & O'Reilly, MK & 32 & 6.40 & 2 \\
\hline 95 & $\begin{array}{l}\text { Virtual cerebral Ventricular } \\
\text { system: an MR-based three- } \\
\text { dimensional computer model }\end{array}$ & $\begin{array}{l}\text { Anatomical } \\
\text { Sciences } \\
\text { Education }\end{array}$ & 4 & 2011 & Adams, CM & 32 & 3.20 & 0 \\
\hline 96 & $\begin{array}{l}\text { Using 3D modeling } \\
\text { techniques to enhance } \\
\text { teaching of difficult } \\
\text { anatomical concepts }\end{array}$ & $\begin{array}{l}\text { Academic } \\
\text { Radiology }\end{array}$ & 23 & 2016 & Pujol, S & 31 & 6.20 & 2 \\
\hline 97 & $\begin{array}{l}\text { Utilising mobile-augmented } \\
\text { reality for learning human } \\
\text { anatomy }\end{array}$ & $\begin{array}{l}\text { Conference: } 7 \text { th } \\
\text { World Conference } \\
\text { on Educational } \\
\text { Sciences Location: } \\
\text { Athens, GREECE }\end{array}$ & & 2015 & Jamali, SS & 31 & 5.17 & 0 \\
\hline 98 & $\begin{array}{l}\text { A "Second Life" for gross } \\
\text { anatomy: applications for } \\
\text { multiuser virtual } \\
\text { environments in teaching the } \\
\text { anatomical sciences }\end{array}$ & $\begin{array}{l}\text { Anatomical } \\
\text { Sciences } \\
\text { Education }\end{array}$ & 4 & 2011 & Richardson, A & 31 & 3.10 & 0 \\
\hline 99 & $\begin{array}{l}\text { Comparison of computer- } \\
\text { based and paper-based } \\
\text { imagery strategies in learning } \\
\text { anatomy }\end{array}$ & Clinical Anatomy & 18 & 2005 & Khalil, MK & 30 & 1.88 & 0 \\
\hline 100 & $\begin{array}{l}\text { Current applications and } \\
\text { future perspectives of the use } \\
\text { of 3D printing in anatomical } \\
\text { training and neurosurgery }\end{array}$ & $\begin{array}{l}\text { Frontiers in } \\
\text { Neuroanatomy }\end{array}$ & 24 & 2016 & Baskaran, V & 29 & 5.80 & 2 \\
\hline
\end{tabular}

\section{REFERENCES}

1. Estai M, Bunt S. Best teaching practices in anatomy education: a critical review. Ann Anat 2016;208:151-7.
2. Hu M, Wattchow D, de Fontgalland D. From ancient to avant-garde: a review of traditional and modern multimodal ap- 
proaches to surgical anatomy education. ANZ J Surg. 2018;88:146-51.

3. Craig S, Tait N, Boers D, McAndrew D. Review of anatomy education in Australian and New Zealand medical schools. ANZ J Surg. 2010;80:212-6.

4. Johnson EO, Charchanti AV, Troupis TG. Modernization of an anatomy class: from conceptualization to implementation. A case for integrated multimodal-multidisciplinary teaching. Anat Sci Educ 2012;5:354-66.

5. Joyce CW, Joyce KM, Sugrue CM, Kelly JC, Carroll SM, Kerin MJ, et al. Plastic Surgery and the Breast: A Citation Analysis of the Literature. Plast Reconstr Surg Glob Open 2014;2:e251. 6. Tibor B, Wolfgang G, András S.A. Hirsch-type index for journals. Scientometrics 2006;69:169-73.

7. Scimago Lab. Scimago Journal \& Country Rank. Available from: http://www.scimagojr.com. Accessed February 8, 2020.

8. Zerem E. The ranking of scientists based on scientific publications assessment. J Biomed Inform 2017;75:107-9.

9. Li K, Rollins J, Yan E. Web of Science use in published research and review papers 1997-2017: a selective, dynamic, crossdomain, content-based analysis. Scientometrics 2018;115:1-20. 10. Celik E, Dokur M, Uysal BB, Şengül Samancı N, Demirelli FH. Comparison of attention for cancer research on social media versus academia: an altmetric score znalysis. J Hematol Oncol 2020;30:32-42.

11. Garfield E. Citation analysis as a tool in journal evaluation. Science 1972; 178:471.

12. Seglen PO. Why the impact factor of journals should not be used for evaluating research. BMJ 1997;314:498-502.

13. Altmetric. When did Altmetric start tracking attention to each attention source? Available from: https://help.altmetric.com/support/solutions/articles/6000136884-when-did-altmetric-starttracking-attention-to-each-attention-source-. Accessed February $15,2019$.

14. Trueger NS, Thoma B, Hsu CH, Sullivan D, Peters L, Lin M. The altmetric score: a new measure for article-level dissemination and impact. Ann Emerg Med 2015;66:549-53.

15. Kim Y, Kim JE, Kim YH, Yoon DY, Kim YJ, Bae JS. Social attention and scientific articles on stroke: Altmetric analysis of top-50 articles. Clin Neurol Neurosurg 2019;183:105386.

16. Altmetric. How is the Altmetric Attention Score calculated? Available from: https:/help.altmetric.com/support/solutions/articles/6000060969-how-is-the-altmetricattention-score-calculated. Accessed February 15, 2019.
17. Arigo D, Pagoto S, Carter-Harris L, Lillie SE, Nebeker C. Using social media for health research: methodological and ethical considerations for recruitment and intervention delivery. Digit Health 2018;4:2055207618771757.

18. Altmetric. The donut and Altmetric Attention Score. Available from: https://www.altmetric.com/about-our-data/the-donut-andscore/. Accessed February 15, 2019.

19. Silverstein JC, Walsh C, Dech F, Olson EC, Papka ME, Parsad NM, et al. Immersive virtual anatomy course using a cluster of volume visualization machines and passive stereo. Stud Health Technol Inform 2007;125:439-44.

20. Marsland MJ, Lazarus MD. Ask an anatomist: Identifying global trends, topics and themes of academic anatomists using twitter. Anat Sci Educ 2018;11:270-81.

21. Jaffar AA. Exploring the use of a Facebook page in anatomy education. Anat Sci Educ 2014;7:199-208.

22. Pant S, Deshmukh A, Murugiah K, Kumar G, Sachdeva R, Mehta JL. Assessing the credibility of the "YouTube approach" to health information on acute myocardial infarction. Clin Cardiol 2012;35:281-5.

23. Camm CF, Sunderland N, Camm JA. A quality assessment of cardiac auscultation material on YouTube. Clin Cardiol 2013;36:77-81.

24. Jaffar AA. YouTube: an emerging tool in anatomy education. Anat Sci Educ 2012;5:158-64.

25. Sutherland S, Jalali A. Social media as an open-learning resource in medical education: current perspectives. Adv Med Educ Pract 2017;8:369-75.

26. Winkelmann A. Anatomical dissection as a teaching method in medical school: a review of the evidence. Med Educ 2007;41;15-22.

27. Wilson AB, Miller CH, Klein BA, Taylor MA, Goodwin M, Boyle EK, et al. A meta-analysis of anatomy laboratory pedagogies. Clin Anat 2018;31;122-33.

28. Petersson H, Sinkvist D, Wang C, Smedby O. Web-based interactive 3D visualization as a tool for improved anatomy learning. Anat Sci Educ 2009;2:61-8.

29. Persaud TVN. The early history of human anatomy: from antiquity to the beginning of the modern area. Med Hist 1984;31;478-9.

30. eBizMBA Inc. Top 15 Most Popular Websites | February 2020. Available from: http://www.ebizmba.com/articles/mostpopular-websites. Accessed February 15, 2019. 